\title{
Thesaurus as a Tool for Teaching Abstract Writing to Graduate Students
}

\author{
Marina M. Bazhutina ${ }^{1, *}$, Olga N. Brega ${ }^{1}$ \\ ${ }^{1}$ Togliatti State University, Togliatti, Russia, Theory and Practice of Translation Department, 445667, Togliatti, Russia
}

\begin{abstract}
This study, grounded on the need in the permanent development of competences formation methodologies to meet employers' demand, presents an effective didactic tool for teaching ESP to graduate students. The paper describes thesaurus modelling principles applied to teaching foreign language terminology to students of Welding Production Technology and Equipment at Togliatti State University. It was discovered that semantic relations between thesaurus items correlate with relations between research methodology components. Then the authors propose three stages which enable educators both to organize their term management work and to train a metalinguistic competence in scholarly abstract writing. The first stage contains two algorithms of building a thesaurus based on inductive and deductive methods of thinking accordingly. At the second stage the semantic relations between thesaurus items are used to determine methodology components of a bachelor's thesis by means of correlating these semantic relations to the relations between research methodology components. At the final stage common cliches for abstract writing are introduced to students.
\end{abstract}

\section{Introduction}

A clear understanding of the need to change in accordance with time and social requirements leads to continuous processes of transformation both in industrial and scientific fields, and in the field of higher professional education. These conditions as suggested by many researchers $[1,2]$ relate closely to employers' demands. In case of Togliatti State University, regional economy with its constant demand for innovations on an international scale determines the content of syllabi of engineering majors since international enterprises in the automotive industry and mechanical engineering are the main employers. Part of the university's syllabi is a number of ESP courses for students of non-linguistic majors, and a constant analysis of economic changes and survey of employers' demand make us take into account the necessity of new competencies, effective tools for their building, and development of the educational programs because the main goal of vocational training is to prepare graduates for successful and efficient professional activity. This does not simply mean to give knowledge of a foreign language, but, firstly, to form the ability to work with authentic scientific sources, secondly, to form students' readiness for foreign language professional communication, thirdly, to teach metalanguage of a professional subject area. Moreover, according to the requirements for writing a bachelor's thesis at Togliatti State University graduate students are supposed to write an abstract in English of their bachelor's theses. Consequently, specific instructions on abstract writing are relevant.
In our opinion, it is important to form the competence of terminology accumulation in a thesaurus as the lexicographic description of individual metalanguage, in order to include professional terms into speech correctly. Our teaching experience shows that there is a lack of professional speech skills for using terms, or misuse as a result of confusion in matching Russian and English terminological units, which reveals the relevance of the problem and dictates the need to improve the methodological organization of the educational process. Thus, the premise of the paper is that thesaurus modelling is applicable to teaching terminology and abstract writing skills as well as building students' theoretical thinking and scholarly writing.

\section{Methodology}

Focusing on the National Doctrine of Education [3] and the corresponding section of the Federal State Education Standards (FSES) of the third generation of the bachelor's degree syllabi in Welding Production Technology and Equipment at Togliatti State University [4], it should be noted that new technologies in mastering foreign languages emerge due to the demand of specialists competent in scientific and technical intercultural communication, able to adapt to modern and rapidly changing conditions of international labour market. Students are supposed to acquire knowledge of basic terminological vocabulary, to use professional speech patterns, to be able to work with foreign language sources of information and terminological dictionaries, to translate and understand technical texts to solve problems

\footnotetext{
* Corresponding author: kurs-veka21@yandex.ru
} 
of professional interpersonal and intercultural interaction and to have the ability to abstract academic and professional texts. Thus, the metalinguistic competence is an obligatory component of communicative competence in oral and written forms in a foreign language. Mastering the metalinguistic competence is, no doubt, part and parcel of teaching professional communication in a foreign language.

Turning to the works that highlight professional terminology mastering, we rely on a number of studies that make up the basis for the formation of the professional foreign language metalinguistic competence with the help of a training thesaurus in a particular subject area. Thus, it is important to take into account theoretical approaches that reveal the mechanisms of the linguistic identity formation [5-7] and the second linguistic identity [8], various aspects of features of a terminological language sign [9], existing traditions in academic lexicography $[10,11]$ and thesaurus modelling principles in teaching professional vocabulary $[12,13]$. Moreover, recent studies have shown that graduate students must be able to manage the terminology and keep up with technological developments. Technical communicators are supposed not only to translate, but to localize and identify the terminology of the subject area, select the equivalents in the target language and build official terminology bases for further machine translation [14], and the bachelor's language training planning should be based on the ideas highlighted in the works on effective techniques for scholarly writing by M.J. Harris, who illustrates special techniques for article abstract writing, and describes the students' success after having implemented his instructional model [15].

As it is known, the term is a more complex phenomenon than it might seem at first glance: the same term can perform different functions in a sentence, have different forms and collocations with other terminological units. Terms may be homophones, homographs, have many overlapping meanings, and different terms may have the same or similar meaning, but are used in different situations. The terminological unit, being a complex semiotic unit with a multitude of components, is included into the system of a professional subject area entering into whole/part, or part/whole relations, taxonomy and attributive relations. These relations are the result of the cognitive study of language, and the cognitive aspect of thesaurus modelling can be turned into finding out its connection with determination of research methodology components. The latter is part of professional competence of bachelors of Science.

The main idea of the present paper is just about the cognitive (logical) aspect of thesaurus modelling and thus finding this very connection with the determination of research methodology components which enables students to master basic academic skills of research and describing its results in an abstract of the bachelor's thesis. Therefore, creating effective teaching technologies based on lexicographic achievements is essential for building metalinguistic knowledge, skills and abilities that make up the metalinguistic competence.

It has been shown that an individual training thesaurus enables students to describe their professional areas with the help of concepts and terms relevant for their future profession; it also creates a holistic vision of a particular profession and forms positive motivation for communicative competence development. So in this paper we focus on teaching English for special purposes includes mastering professional terminology, for example, that of welding production technology and equipment.

The authors' work experience shows that thesaurus modelling is successfully used as a linguo-didactic tool for forming professional translation competence of students of Linguistics [13]. Principles of thesaurus modelling are being successfully tested in teaching ESP to students of non-linguistic majors.

So this paper is aimed at:

- showing how it is possible to adapt basic thesaurus modelling principles to building a thesaurus of professional subject areas in teaching ESP for students of non-linguistic majors;

- showing how it is possible to pre-teach research methodology components on the basis of thesaurus modelling before students start writing their bachelor's theses.

- working out a scheme of teaching abstract writing based on thesaurus modelling.

\section{Determining methodology components by means of thesaurus semantic relations}

First of all, we have discovered that semantic relationships between terms of a particular subject area are the same as those between the components of research methodology of a bachelor's thesis. Namely, the hyperonym/hyponym (taxonomy) and holonym/ meronym (whole/part) relationships found between the field and the general terms in a thesaurus, between the general term and other terms are exactly the same as between subject and subject-matter of the bachelor's thesis, its aim and objectives. A number of welding thesaurus general terms have attributes which denote process (object) attributes and their semantic relationships are also revealed, and the latter correspond to the connection between subject-matter and practical significance. These correlations are exemplified in the table below.

Table 1. Methodology components viewed through semantic relations.

\begin{tabular}{|l|c|c|c|}
\hline $\begin{array}{l}\text { Methodology } \\
\text { components }\end{array}$ & $\begin{array}{c}\text { Hyperonym/ } \\
\text { hyponym }\end{array}$ & $\begin{array}{c}\text { Holonym/ } \\
\text { meronym }\end{array}$ & $\begin{array}{c}\text { Process } \\
\text { (object)/ } \\
\text { attributes }\end{array}$ \\
\hline $\begin{array}{l}\text { Subject/ } \\
\text { Subject- } \\
\text { matter }\end{array}$ & + & + & \\
\hline $\begin{array}{l}\text { Aim/Objectiv } \\
\text { es }\end{array}$ & ++ & + \\
\hline $\begin{array}{l}\text { Subject- } \\
\text { matter/Aim/ } \\
\text { Results }\end{array}$ & + & + & + \\
\hline $\begin{array}{l}\text { Subject- } \\
\text { matter/Aim/ }\end{array}$ & + & & + \\
\hline
\end{tabular}




\begin{tabular}{|l|l|l|l|}
\hline $\begin{array}{l}\text { Results/ } \\
\text { Practical } \\
\text { significance }\end{array}$ & & & \\
\hline
\end{tabular}

Secondly, we put forward the following strategies for developing scientific thinking by means of the English language:

- to describe research methodology of the bachelor's thesis;

- to disclose interdisciplinary links in professional subjects.

The idea is to show how graduate students can transform their professional knowledge and the scope of their major into components of research methodology by means of describing semantic relations between professional terms within thesaurus semantic fields.

e.g. Welding is used both in construction and repair works (1), and it falls into several types, e.g. semiautomatic welding (2). The latter has its welding method (3). A welding method has its attributes: cost and productivity. To work out the most productive and costsaving welding method is the aim of any production process because such method reduces its cost (4). So this brief outline of welding enables us to come to the following logical sequence:

1 ) relevance $\rightarrow 2$ ) subject $\rightarrow 3$ ) subject-matter $\rightarrow 4$ ) aim/objectives and practical significance.

\section{Scheme of teaching abstract writing based on thesaurus modelling}

These strategies help to achieve more specific goals, i.e. acquiring certain skills of academic writing - writing an abstract of the bachelor's thesis. That is why we have worked out a scheme of teaching abstract writing based on thesaurus modelling. It comprises the following stages: I. Working out a thesaurus building algorithm to be used by students.

II. Working with tables containing thesaurus items and methodology components described in the abstract of a bachelor's thesis.

III. Introducing common cliches for abstract writing.

Below these stages are given in details.

\subsection{Thesaurus building algorithm}

\subsubsection{From the field to the general term}

To work out a thesaurus building algorithm it is necessary to preliminary single out two approaches. The first one is based on the deductive way of thinking, and this algorithm is called From the Field to the General Term Algorithm. It runs as follows.

1. Within your major you should single out a few subject areas.

2. Before building up a thesaurus you need to instruct students about the basic correlations of items in their thesauruses.

3. Make up graphs classifying each area on the basis of the hyperonym/hyponym relationships. E.g. within the welding production technology and equipment major it is possible to classify welding into its several types which are, in their turn, extended subject areas. Applying thesaurus modelling terminology, we name them semantic fields or just fields. 4.

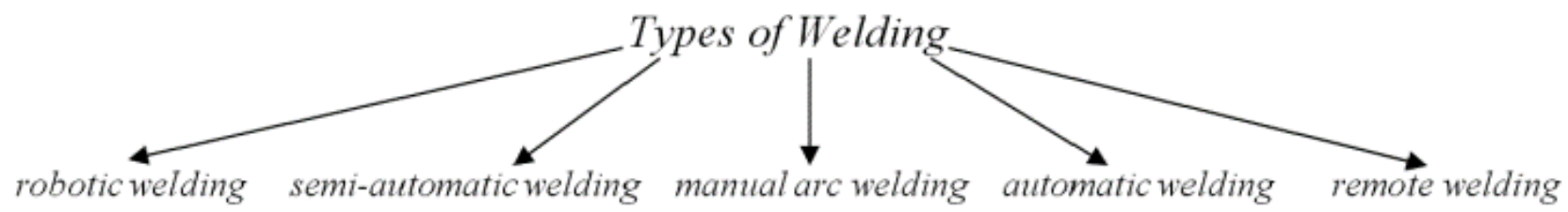

Fig. 1. Semantic field "Types of Welding".

Fill in the table spaces named "Field" in the template table with the names of semantic fields (see Table 2).

4. Within the field "semi-automatic welding" it is necessary to find general terms, i.e. concepts representing the field. The first general term is equipment which is a holonym because it is classified into more specific terms - meronyms which denote parts of a whole, i.e. welding equipment components. The graph representation of this general term is given below.

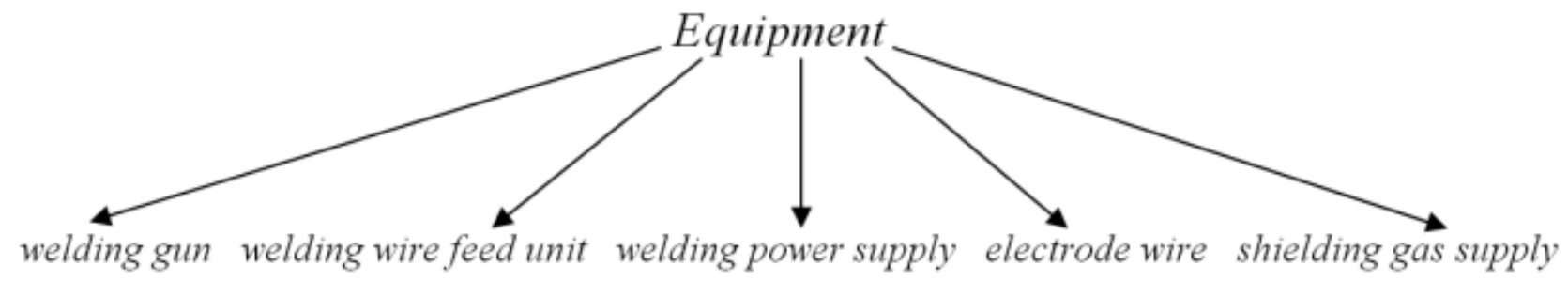

Fig. 2. Semantic field "Equipment".

Then the term equipment is placed into the general term line in your thesaurus. The names of components of welding equipment are placed in the hyperonym lines.
5. A piece of equipment, for example, a welding gun consists of parts, and their names relate to the names of the piece of equipment as part to the whole. So a welding 
gun (a holonym) consists of: 1) a control switch; 2) a contact tip; 3) a power cable; 4) a gas nozzle; 5) an electrode conduit; 6) a liner; 7) a gas hose. These terms are meronyms. The corresponding lines based on these graphs are singled out.

6. After that students may continue selecting general terms, for example, in the semantic field of semiautomatic welding (welding method, shielding gas) according to the scope of their research. If the aim is to represent as many welding concepts as possible, students may continue selecting new fields according to their major.

7. If the general term denotes a process so it may have characteristics which go to the process attributes line.

8. If the general term denotes an object which possesses some properties so the corresponding terms go to the object attributes line.

Below there is a sample of the English-Russian thesaurus in the subject area of welding production technology and equipment which is built up before students proceed to write their bachelor's theses.

Table 2. Fragment of the Russian-English thesaurus of welding production technology and equipment.

\begin{tabular}{|c|c|c|}
\hline $\begin{array}{c}\text { Thesaurus } \\
\text { item }\end{array}$ & English & Russian \\
\hline FIELD & $\begin{array}{c}\text { SEMI- } \\
\text { AUTOMATIC } \\
\text { WELDING }\end{array}$ & $\begin{array}{l}\text { МЕХАНИЗИРО- } \\
\text { ВАННАЯ СВАРКА }\end{array}$ \\
\hline General term & $\begin{array}{l}\text { 1. Equipment } \\
\text { and materials }\end{array}$ & $\begin{array}{l}\text { 1. Оборудование и } \\
\text { материалы }\end{array}$ \\
\hline \multirow{3}{*}{$\begin{array}{c}\text { Hyperonym/ } \\
\text { hyponym }\end{array}$} & welding gun & сварочный пистолет \\
\hline & wire feed unit & $\begin{array}{c}\text { механизм подачи } \\
\text { проволоки }\end{array}$ \\
\hline & & . \\
\hline \multirow[t]{4}{*}{$\begin{array}{c}\text { Holonym/ } \\
\text { meronym }\end{array}$} & welding gun: & сварочный пистолет: \\
\hline & control switch & командоаппарат \\
\hline & contact tip & $\begin{array}{l}\text { контактный } \\
\text { наконечник }\end{array}$ \\
\hline & coppered wire & $\begin{array}{c}\text { омеднённая } \\
\text { проволока }\end{array}$ \\
\hline \multirow[t]{4}{*}{$\begin{array}{c}\text { Object } \\
\text { attributes }\end{array}$} & coppered wire: & $\begin{array}{l}\text { омеднённая } \\
\text { проволока: }\end{array}$ \\
\hline & weld chemistry & химический состав \\
\hline & strength & прочность \\
\hline & cost & себестоимость \\
\hline General term & $\begin{array}{l}\text { 2. Zinced } \\
\text { pipeline }\end{array}$ & $\begin{array}{l}\text { 2. Оцинкованный } \\
\text { трубопровод }\end{array}$ \\
\hline \multirow[t]{2}{*}{$\begin{array}{l}\text { Holonym/ } \\
\text { meronym }\end{array}$} & zinced pipe & оцинкованная труба \\
\hline & & $\ldots$ \\
\hline General term & $\begin{array}{l}\text { 3. Welding } \\
\text { method: }\end{array}$ & 3. Метод сварки: \\
\hline \multirow[t]{2}{*}{$\begin{array}{l}\text { Process } \\
\text { attributes }\end{array}$} & cost & себестоимость \\
\hline & productivity & производительность \\
\hline General term & 4. Shielding gas: & 4. Защитный газ: \\
\hline \multirow[t]{3}{*}{$\begin{array}{c}\text { Hyperonym/ } \\
\text { hyponym }\end{array}$} & oxyacetylene & $\begin{array}{c}\text { ацетилено- } \\
\text { кислородный }\end{array}$ \\
\hline & argon & аргон \\
\hline & 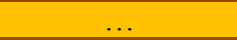 & \\
\hline
\end{tabular}

\begin{tabular}{|c|c|c|}
\hline FIELD & $\begin{array}{c}\text { MANUAL ARC } \\
\text { WELDING }\end{array}$ & $\begin{array}{c}\text { РУЧНАЯ ДУГОВАЯ } \\
\text { СВАРКА }\end{array}$ \\
\hline General term & 5. Corrosion & $\begin{array}{c}\text { 5. Коррозийные } \\
\text { разрушения }\end{array}$ \\
\hline$\ldots$ & $\ldots$ & $\ldots$ \\
\hline
\end{tabular}

\subsubsection{From the general term to the field}

Should students work with technical texts they may follow the inductive approach to thesaurus building, and From the General Term to the Field Algorithm can be used:

1. Pick out terms which may turn out to be general terms for your thesaurus. The list of keywords for a paper may well serve as general terms for the subject area (field) in your thesaurus.

2. Determine what field each term belongs to.

3. Define whether the found terms:

- denote a whole concept or its part;

- represent a general concept, i.e. serve as a basis for classification into types;

- have attributes.

4. Consider the text's subject-matter as a title for your thesaurus.

\subsection{Working with tables for thesaurus items and methodology components of a bachelor's thesis}

Here we pass on to the second stage when we offer tables demonstrating the correlation of thesaurus items in comparison with relations between research methodology components which are to be described in the abstract of a bachelor's thesis. Completing the table template (table 3 ) with thesaurus terms consists of the following steps:

- Students provide examples for basic types of relations between thesaurus terms: hyperonym/hyponym (taxonomy relations), holonym/meronym (whole/part relations), process attributes, object attributes.

- The correlations of thesaurus items with research methodology components are provided by the teacher.

- The individual thesaurus is transformed into the components of research methodology by means of filling in the following template table (table 3 ).

Table 3. Semantic relations between thesaurus items in comparison with relations between research methodology components (template table).

\begin{tabular}{|l|l|l|l|l|}
\hline $\begin{array}{l}\text { Thesaurus } \\
\text { items } \\
\text { correlation }\end{array}$ & $\begin{array}{l}\text { Hyper- } \\
\text { onym/ } \\
\text { hyponym }\end{array}$ & $\begin{array}{l}\text { Hol- } \\
\text { onym/ } \\
\text { meronym }\end{array}$ & $\begin{array}{l}\text { Process } \\
\text { (object/ } \\
\text { attributes }\end{array}$ & $\begin{array}{l}\text { Method- } \\
\text { ology } \\
\text { com- } \\
\text { ponents }\end{array}$ \\
\hline $\begin{array}{l}\text { Field/ } \\
\text { general } \\
\text { term }\end{array}$ & & & & $\begin{array}{l}\text { Subject/ } \\
\text { Subject- } \\
\text { matter }\end{array}$ \\
\hline $\begin{array}{l}\text { General } \\
\text { term/ } \\
\text { process } \\
\text { attributes }\end{array}$ & & & & $\begin{array}{l}\text { Aim/ } \\
\text { Object- } \\
\text { ives }\end{array}$ \\
\hline $\begin{array}{l}\text { Field/ } \\
\text { general } \\
\text { term/ }\end{array}$ & & & & $\begin{array}{l}\text { Subject- } \\
\text { matter/ } \\
\text { Aim/ }\end{array}$ \\
\hline
\end{tabular}




\begin{tabular}{|l|l|l|l|l|}
\hline $\begin{array}{l}\text { process } \\
\text { attributes }\end{array}$ & & & $\begin{array}{l}\text { Results/ } \\
\text { Practical } \\
\text { signific- } \\
\text { ance }\end{array}$ \\
\hline
\end{tabular}

As the template table is filled in, students acquire the idea of how methodology components of a bachelor's thesis are determined. The suggested table 4 serves as a sample and may be modified according to the major. The number of thesaurus items correlations may also vary if it required by the subject of research. The correlation between the general term and process attributes is repeated to show that this type of semantic relations is represented in two correlations of methodology components.

Table 4. Semantic relations between thesaurus items in comparison with relations between research methodology components.

\begin{tabular}{|l|l|l|l|l|}
\hline $\begin{array}{l}\text { Thesaurus } \\
\text { items } \\
\text { correlation }\end{array}$ & $\begin{array}{l}\text { Hyper- } \\
\text { onym/ } \\
\text { hyponym }\end{array}$ & $\begin{array}{l}\text { Hol- } \\
\text { onym/ } \\
\text { merony } \\
\text { m }\end{array}$ & $\begin{array}{l}\text { Process } \\
\text { (object)/ } \\
\text { attributes }\end{array}$ & $\begin{array}{l}\text { Method- } \\
\text { ology } \\
\text { com- } \\
\text { ponents }\end{array}$ \\
\hline $\begin{array}{l}\text { Field/ } \\
\text { general } \\
\text { term }\end{array}$ & $\begin{array}{l}\text { Semi- } \\
\text { automatic } \\
\text { welding/ } \\
\text { welding } \\
\text { method }\end{array}$ & - & - & $\begin{array}{l}\text { Subject/ } \\
\text { Subject- } \\
\text { matter }\end{array}$ \\
\hline $\begin{array}{l}\text { General } \\
\text { term/ } \\
\text { process } \\
\text { attributes }\end{array}$ & - & - & $\begin{array}{l}\text { Welding } \\
\text { method/ } \\
\text { cost, } \\
\text { product- } \\
\text { ivity }\end{array}$ & $\begin{array}{l}\text { Aim/ } \\
\text { Object- } \\
\text { ives }\end{array}$ \\
\hline $\begin{array}{l}\text { General } \\
\text { term/ } \\
\text { process } \\
\text { attributes }\end{array}$ & - & - & $\begin{array}{l}\text { Welding } \\
\text { method/ } \\
\text { cost, } \\
\text { product- } \\
\text { ivity }\end{array}$ & $\begin{array}{l}\text { Subject- } \\
\text { matter/ } \\
\text { Aim// } \\
\text { Results/ } \\
\text { Practical } \\
\text { signific- } \\
\text { ance }\end{array}$ \\
\hline
\end{tabular}

\subsection{Introducing common cliches for abstract writing}

Since an abstract of a bachelor's thesis definitely includes the description of methodology components (which is the invariable part, and research details are optional), we give a list of some common cliches for their description only.

Table 5. Basic speech patterns for abstract writing.

\begin{tabular}{|l|l|}
\hline \multicolumn{1}{|c|}{$\begin{array}{c}\text { Methodology } \\
\text { components }\end{array}$} & \multicolumn{1}{c|}{ Cliches } \\
\hline $\begin{array}{l}\text { Subject/Subject- } \\
\text { matter }\end{array}$ & $\begin{array}{l}\text { The bachelor's thesis is devoted to } \\
\ldots \text { The subject is ... } \\
\text { Its subject-matter is ... }\end{array}$ \\
\hline Aim/Objectives & $\begin{array}{l}\text { The aim of the present study is ... } \\
\text { To achieve this aim we put forward } \\
\text { the following objectives ... } \\
\text { The objectives include ... }\end{array}$ \\
\hline Results & $\begin{array}{l}\text { We also report the results of } \\
\text { experiments conducted to explore } \\
\text { ways to... } \\
\text { The results show clearly that ... } \\
\text { The results of the bachelor's thesis } \\
\text { demonstrate ... }\end{array}$ \\
\hline
\end{tabular}

\begin{tabular}{|l|l|}
\hline Practical significance & The practical significance lies in ... \\
\hline Structure & The bachelor's thesis consists of ... \\
\hline
\end{tabular}

Below is a sample of an abstract based on the welding thesaurus:

The bachelor's thesis is devoted to the welding of the zinced pipeline for industrial buildings. The subject is semi-automatic welding. The subject-matter is a welding method that enables to increase productivity and to reduce production costs. The aim of the present study is to discover a method of increasing the productivity of welding the zinced pipeline for industrial buildings.

The objectives include describing welding methods which are used in pipeline welding; working out a welding method for a zinced pipeline; calculating its cost in comparison with the other welding methods. The results of the bachelor's thesis demonstrate a method for joining pipes using semi-automatic welding in a shielding gas with flux paste.

The practical significance lies in discovering the welding method that enables to increase productivity and to reduce production costs.

The bachelor's thesis consists of 53 pages of the printed text. The graphical part of the work contains six posters: the diagram and the overall view of the galvanized pipeline for industrial buildings; the analysis of possible welding methods; technological process; equipment and devices for the zinced pipeline production.

\section{Conclusion}

Thus, thesaurus modelling enables students of nonlinguistic majors to acquire the mechanism of determining research methodology components by means of working with professional terms. It also helps to develop scientific thinking, which is important for writing yearly essays and bachelor's theses. Another benefit of acquiring principles of thesaurus modelling is that thesaurus general terms may well serve as key words for searching professional texts in data bases. The proposed teaching method is meant for further development of scholarly writing skills, namely, teaching abstract writing in English (abstracts of academic papers) to master students. The prospects of our research are aimed at further development of metalinguistic competence formation as part of students' communicative competence on the basis of professional thesaurus modelling.

\section{References}

1. K. Bezukladnikov, B. Zhigalev, A. Prokhorov, B. Cruze, Language and culture, 42, 163-180, (2018)

2. V. Lizunkov, V. Marchuk, E. Malushko, O. Maletina, A. Zavjyalova, The European Proceedings of Social and Behavioural Sciences, 19, 456-463 (2017)

3. A. Khutorskoy, Higher Education in Russia, 12, 8591 (2017)

4. Federal State Educational Standard of Higher Professional Education for the major 15.03.01«Welding Production Technology and 
Equipment» (level of bachelor)

5. Yu. Karaulov, I. Ruzhickij, Language: quest facts, hypotheses: a collection of articles to the 100anniversary of birthday of academician, 654-659 (2016)

6. V. Karasik, Izvestiya Volgogradskogo gosudarstvennogo pedagogicheskogo universiteta, 3 (116), 88-94 (2017

7. N. Zajceva, Philological Sciences - Theory and practice, 12-3 (66), 103-106 (Gramota, 2016)

8. L. Medvedeva, E. Nadezhdina, Vestnik Tomskogo gosudarstvennogo universiteta, 327, 185-190 (2009)

9. I. Kulikova, D. Salmina, Linguistic terminology in professional aspect, 332 (Own publishing house, 2017)

10. T. Serova, G. Chainikova, Vestnik PNIPU. Problems of linguistics and pedagogy, 1, 144-156 (2018)

11. R. Piotrovskij, A. Popeskul, I. Sovpel, The II International conference "R. Piotrowski's Readings LE \& AL'2017', 2233, 29-36 (Herzen State Pedagogical University, 2017)

12. Yu. Gorbunov, S. Andreev, The II International conference 'R. Piotrowski's Readings LE \& AL'2017”, 2233, 29-36 (Herzen State Pedagogical University, 2017)

13. O. Brega, M. Bazhutina, Karelian scientific journal, 4 (21), 17-21 (2017)

14. L. Beliaeva, V. Chernyavskaya, Journal of Siberian Federal University. Series: Humanities, 12 (1), 30-31 (2019)

15. M.J. Harris, IJTLHE, 17 (2) 136-146 (Texas A\&M University-Texarkana, 2006 